\title{
Breeding habits of vector mosquitoes of filariasis and dengue fever in Western Samoa ${ }^{1)}$
}

\author{
Takeshi SUZUKI* and F. SONE** \\ * WHO Vector Biology and Control Research Unit No. 2, P. O. Box 302, \\ Jakarta, Indonesia \\ ** Apia, Western Samoa
}

(Received: May 16, 1978)

\begin{abstract}
Extensive surveys were undertaken in Western Samoa during the period 1969 to 1971 on breeding habits of the confirmed and suspected vectors of subperiodic Wuchereria banorofti and of Aedes (Stegomyia) aegypti, the vector of dengue fever.

Ae. (S.) aegypti breeds predominantly in artificial water containers around houses. A negligible number was found breeding in tree holes. This mosquito occurs throughout the country, even in the remote and inland areas. Ae. (S.) polynesiensis breeds in a wide range of both artificial and natural containers, but seems to prefer the latter, and is the only species breeding in crab holes. Since the above two species are often found breeding together, the single-larva-per-container survey method tends to underestimate the population of either one. Ae. (S.) upolensis is a forest mosquito, and its larvae were collected only once in a tree hole.

The only species found breeding in the leaf axils of Freycinetia is Ae. (Finlaya) samoanus; and in taro (Colocasia sp.) and pineapples, Ae. $(F$.) oceanicus. Both species can also breed in the Pandanus axils. This plant serves the only breeding habitat for Ae. $(F$.$) tutuilae.$
\end{abstract}

\section{INTRODUCTION}

In Western Samoa, subperiodic banoroftian filariasis had been one of the main communicable diseases of public health importance.

Confirmed vectors of the filariasis are Aedes (Stegomyia) polynesiensis, Ae. (Finlaya) samoanus and Ae. (S.) upolensis. Ae. (F.) tutuilae is suspected to be a vector (Ramalingam and Belkin, 1965 ; Ramalingam, 1968), and $A e .(F$.$) oceanious was reported to$ transmit subperiodic filariasis in Tonga (Hitchcock, 1971). Some studies on breeding

1) This work was studied Intercountry Filariasis Advisory Team.

*鈴木 猛 habits of Ae. polynesiensis were undertaken in American Samoa by Jackowski (1954) and in French Polynesia by Bonnet and Chapman $(1956,1958)$; and these were reviewed by Iyengar (1965). In Western Samoa, systematic studies on the breeding habits of the vectors have been reported only by Ramalingam (1965, 1968).

During the period July 1969 to December 1971, the authors were engaged in the studies on biology, distribution and control of the filariasis vectors, with preliminary studies in 1968, and supplementary studies in 1972 and 1973. In this report, breeding habits of the filariasis vectors and their distribution in the country are presented, together with those of $A e$. (S.) aegypti, the main vector of dengue fever. 


\section{METHODS}

In most surveys, twenty to thirty larvae, or sometimes more, of the third or fourth stage, if enough number present, were collected from each breeding site. In leaf axils of plants, those collected from one bundle of the same kinds of plant were usually pooled in a bottle. Identification was made according to the keys by Belkin (1962) and Ramalingam (1965).

Efforts were concentrated to collect larvae from the water containers near residential areas or plantations; and those breeding either in containers located far from human activities or in non-container habitats, were rarely collected. Sometimes no collections were made from the very common habitats of Aedes larvae, such as coconut shells, even if they were found. Therefore, the number of the breeding sites shown in Table 1 does not reflect the frequency of the positive sites in the country.

Special surveys were made on watercollecting drums, canoes, crab holes and leaf axils of Pandanus plant. Methods of such surveys were described in the relevant chapter.

\section{RESULTS}

1. Mosquito species found during the survey

A total of 70,132 larvae were collected from 876 breeing sites. During the survey, the following ten species in three genera were found.
Aedes (Stegomyia) aegypti
Ae. (S.) polynesiensis
Ae. (S.) upolensis
Ae. (Finlaya) samoanus
Ae. $(F$.) tutuilae
Ae. (F.) oceanicus
Culex (Culex) pipiens fatigans
Culex (C.) annulirostris
Culex (C.) sitiens
Toxorhynchites spp.

The breeding species in each habitat are summarized in Table 1 , and the details are mentioned below.

\section{Breeding species in each habitat}

Artificial water containers.

Drums: In Western Samoa, iron drums with the capacity of 44 imperial gallons, or 200 litres, are widely used for storing water, especially in the villages which have no facilities of pipe water supply. Ae. aegypti, Ae. polynesiensis and Culex p. fatigans breed in the drums. Two of the above three, or even three, were sometimes found breeding together in a drum (Suzuki and Hirshman, 1977).

Special surveys on drums were made by checking all the drums in 15 villages of Upolu Island, 9 villages with pipe water supply, and 6 without it, during the period March to June 1970. As shown in Table 2, in the villages with no water supply, $31.8 \%$ of the houses possess one or more drums, and the number of the drums with larvae was as high as 50.5 per 100 houses. On the contrary, in the villages with pipe water supply, only $5.6 \%$ of the houses possess drum(s), and the number of the drums with larvae was 2.4 per 100 houses.

Canoes: A special survey was made on canoes in six coastal villages of Upolu Island. Every canoe was checked for holding water and harbouring mosquito larvae. Out of 74 canoes checked, 18 or $24 \%$ held water, but none of them harbouring larvae. It should be pointed out that breeding of larvae in canoes is rather rare, but larval population in each positive canoe is usually very high.

Natural water containers excluding leaf axils.

Tree holes: Water collections in tree stumps, tree hollows and trunks of fallen trees are included in this category. Out of 162 trees holes in Table 1, 98 were of coconut trees, 42 of breadfruit trees, and 22 of the other kinds of trees.

As shown in Table 1 , the predominant species in tree holes is Ae. polynesiensis. In one occasion, a hole on a Pandanus plant was found harbouring Ae. polynesiensis, but no Ae. (Finlaya) larvae, which are common in the leaf axils of Pandanus plant. Ae. aegypti larvae were collected from two trunks and one hole of coconut trees in the close proximity of houses. They were associated with Ae.polynesiensis. One Ae. upolensis. larva was collected from a tree hole in a deep forest of Pitonuu Village of 
Table 1 Prevalence of mosquito species in various habitats of Western Samoa

\begin{tabular}{|c|c|c|c|c|c|c|c|c|c|}
\hline \multirow[b]{2}{*}{ Habitat } & \multirow{2}{*}{$\begin{array}{c}\text { No. of } \\
\text { sites } \\
\text { with } \\
\text { larvae }\end{array}$} & \multirow{2}{*}{$\begin{array}{l}\text { No. of } \\
\text { larvae } \\
\text { collect- } \\
\text { ed }\end{array}$} & \multicolumn{7}{|c|}{ No. of each species } \\
\hline & & & $\begin{array}{l}\text { Aedes } \\
\text { polyne- } \\
\text { siensis }\end{array}$ & $\begin{array}{l}\text { Aedes } \\
\text { aegypti }\end{array}$ & $\begin{array}{c}\text { Aedes } \\
\text { upolensis }\end{array}$ & $\begin{array}{c}\text { Aedes } \\
\text { samoanus }\end{array}$ & $\begin{array}{l}\text { Aedes } \\
\text { tutuilae }\end{array}$ & $\begin{array}{l}\text { Aedes } \\
\text { oceanicus }\end{array}$ & $\begin{array}{l}\text { Culex } \\
\text { spp. }\end{array}$ \\
\hline \multicolumn{10}{|c|}{ Artificial water containers and collections } \\
\hline Drum & 113 & 6582 & $\begin{array}{c}779 \\
(11.8 \%)\end{array}$ & $\begin{array}{c}3479 \\
(52.9 \%)\end{array}$ & 0 & 0 & 0 & 0 & $\begin{array}{c}2324 \\
(35.3 \%)\end{array}$ \\
\hline $\begin{array}{l}\text { Tyre and motor } \\
\text { parts }\end{array}$ & 37 & 4622 & $\begin{array}{c}1110 \\
(24.0 \%)\end{array}$ & $\begin{array}{c}1066 \\
(23.1 \%)\end{array}$ & 0 & 0 & 0 & 0 & $\begin{array}{c}2446 \\
(52.9 \%)\end{array}$ \\
\hline Canoe & 6 & 695 & $\begin{array}{c}488 \\
(70.2 \%)\end{array}$ & 0 & 0 & 0 & 0 & 0 & $\begin{array}{c}207 \\
(29.8 \%)\end{array}$ \\
\hline Tin can & 10 & 231 & $\begin{array}{c}226 \\
(97.8 \%)\end{array}$ & $\left(\begin{array}{c}1 \\
0.4 \%\end{array}\right)$ & 0 & 0 & 0 & 0 & $\left(\begin{array}{c}4 \\
(1.7 \%)\end{array}\right.$ \\
\hline Concrete pool & 8 & 235 & $\begin{array}{c}140 \\
(59.6 \%)\end{array}$ & 0 & 0 & 0 & 0 & 0 & $\begin{array}{c}95 \\
(40.4 \%)\end{array}$ \\
\hline Miscellaneous & 6 & 280 & $\begin{array}{c}123 \\
(43.9 \%)\end{array}$ & 0 & 0 & 0 & 0 & 0 & $\begin{array}{c}157 \\
(56.1 \%)\end{array}$ \\
\hline Sub-total & 180 & 12645 & $\begin{array}{c}2866 \\
(22.7 \%)\end{array}$ & $\begin{array}{c}4546 \\
(36.0 \%)\end{array}$ & 0 & 0 & 0 & 0 & $\begin{array}{c}5233 \\
(41.4 \%)\end{array}$ \\
\hline
\end{tabular}

Natural water containers and collections (Excluding leaf axils)

\begin{tabular}{|c|c|c|c|c|c|c|c|c|c|}
\hline Tree hole & 162 & $7314 *$ & $\begin{array}{c}7290 \\
(99.7 \%)\end{array}$ & $\left(\begin{array}{c}12 \\
(0.2 \%)\end{array}\right.$ & $(0.01 \%)$ & 0 & 0 & 0 & $\begin{array}{c}9 \\
(0.1 \%)\end{array}$ \\
\hline Coconut shell & 40 & 3283 & $\begin{array}{c}2502 \\
(76.2 \%)\end{array}$ & 0 & 0 & 0 & 0 & 0 & $\begin{array}{c}781 \\
(23.8 \% \circ)\end{array}$ \\
\hline Crab hole & 59 & 1068 & $\begin{array}{c}1068 \\
(100 \% \text { \% }\end{array}$ & 0 & 0 & 0 & 0 & 0 & 0 \\
\hline Rock hole & 5 & 152 & $\begin{array}{c}76 \\
(50.0 \%)\end{array}$ & 0 & 0 & 0 & 0 & 0 & $\left.\begin{array}{c}76^{\prime} \\
\left(50.0^{\circ} \prime\right.\end{array}\right)$ \\
\hline Miscellaneous & 3 & 27 & $(100 \%)$ & 0 & 0 & 0 & 0 & 0 & 0 \\
\hline Sub-total & 269 & 11844 & $\begin{array}{c}10963 \\
\left(92.6^{\circ} \%\right)\end{array}$ & $\left(\begin{array}{c}12 \\
0.1 \%\end{array}\right.$ & $\left(0.008^{1}(i)\right)$ & 0 & 0 & 0 & $\left(\begin{array}{c}866 \\
\left(7.3^{\circ}\right)\end{array}\right.$ \\
\hline \multicolumn{10}{|c|}{ leaf axils of plants } \\
\hline Pandanus & 299 & 26899 & $\left(\begin{array}{c}53 \\
\left(0.2^{\circ} \%\right.\end{array}\right)$ & 0 & 0 & $\begin{array}{c}18557 \\
(69.0 \%)\end{array}$ & $\left(\begin{array}{l}2252 \\
8.4 \%\end{array}\right)$ & $\begin{array}{c}6037 \\
(22.4 \%)\end{array}$ & () \\
\hline Freycinetia & 18 & 717 & 0 & 0 & 0 & $\begin{array}{c}717 \\
(100 \%)\end{array}$ & 0 & 0 & 0 \\
\hline Taro & 105 & 17914 & $\left(\begin{array}{c}3 \\
(0.02 \%)\end{array}\right.$ & 0 & 0 & $(0.01 \stackrel{2}{\%} \%)$ & 0 & $\begin{array}{c}17909 \\
(99.97 \%)\end{array}$ & 0 \\
\hline Pineapple & 5 & 113 & 0 & 0 & 0 & 0 & 0 & $\begin{array}{c}113 \\
(100 \%)\end{array}$ & ) \\
\hline Sub-total & 427 & 45643 & $(0.1 \%)$ & 0 & 0 & $\begin{array}{c}19276 \\
(42.2 \%)\end{array}$ & $\left(\begin{array}{l}2252 \\
(4.9 \%)\end{array}\right.$ & $\begin{array}{c}24059 \\
(52.7 \%)\end{array}$ & 0 \\
\hline
\end{tabular}

* Toxorhynchites spp. (2 larvae, $0.03 \%)$ were excluded from the breakdown.

Savaii Island.

In the rainy season, many tree holes hold water and allow mosquito larvae to develop, but in the dry season, the holes readily get dry; consequently no larvae can develop any more, although dormant eggs may still be present. This is especially true in the tree holes of the village area, which are not covered by dense forests but rather exposed.

The follow-up checks of 15 tree holes along the northern coast of Upolu Island, which held water on February 1970, showed the following results: Average number of holes with water was 14.3 in March, 11.5 in April, 
Table 2 Results of special survey of water-collecting drums in Western Samoa

\begin{tabular}{lcccccc} 
Type of village & $\begin{array}{c}\text { No. of } \\
\text { villages } \\
\text { under survey }\end{array}$ & $\begin{array}{c}\text { No. of } \\
\text { houses under } \\
\text { survey }\end{array}$ & $\begin{array}{c}\text { No. of } \\
\text { houses with } \\
\text { drum }(\mathbf{s})\end{array}$ & $\begin{array}{c}\text { Total no. } \\
\text { of drums }\end{array}$ & $\begin{array}{c}\text { Total drums } \\
\text { with larvae }\end{array}$ & $\begin{array}{c}\text { No. of drums } \\
\text { with larvae } \\
\text { per } 100 \\
\text { houses }\end{array}$ \\
\hline $\begin{array}{l}\text { With no pipe } \\
\text { water supply }\end{array}$ & 6 & 192 & $61(31.8 \%)$ & 344 & $97(28.2 \%)$ & 50.5 \\
$\begin{array}{l}\text { With pipe } \\
\text { water supply }\end{array}$ & 9 & 413 & $23(5.6 \%)$ & 39 & $10(25.6 \%)$ & 2.4 \\
Overall & 15 & 605 & $84(13.9 \%)$ & 383 & $107(27.9 \%)$ & 17.7 \\
\hline
\end{tabular}

7.0 in May, 10.0 in June, 8.5 in July, 6.0 in August, 6.0 in September, 11.0 in October, 15.0 in November, 7.0 in December, and 10.0 in January 1971.

Similar survey showed that, of 22 tree holes holding water when registered in April 1972 , the average number of the holes with water decreased to 19.5 in May, to 15.3 in June, and to 14.0 in July.

Crab holes: Ae. polynesiensis is the only species breeding in crab holes.

A special survey on crab holes were made in six coastal villages of Upolu and Savaii Islands. About two litres of water, (if water was less than two litres, as much water as collectable), was pumped up from each hole with a plastic tube connected to a bottle and a suction pump. Water was more easily pumped up when tide was high, presumably because water level in the hole fluctuates with tide. The distance from the ground surface to the water level was usually one to six feet, when measured along the crooked hole.

As shown in Table 3, mosquito breeding was found only in two villages, Mulinuu and Moataa, both with sandy beach under co- conut trees. The proportion of positive crab holes to those with water was $68.0 \%$ in Mulinuu and $37.5 \%$ in Moataa.

Salinity of the water from 21 crab holes in Mulinuu and Moataa was examined by titration method with silver nitrate. The maximum and average contents of sodium chloride in water from positive holes were $0.74 \%$ and $0.18 \%$, respectively, while those from negative holes were $1.82 \%$ and $0.63 \%$, respectively. Ae. polynesiensis can breed in slightly salty water, up to $0.74 \%$ of sodium chloride, but can not breed in more salty water. This might be one of the reasons, if not all, that breeding of Ae. polynesiensis in crab holes is limited to some areas, although crab holes are distributed extensively along the coast.

Leaf axils of plants.

Pandanus plant: Pandanus plant is common in and around every village in Western Samoa, and of economic importance for making baskets and mats.

Ae. samoanus, Ae.tutuilae and Ae. oceanicus are the most common species breeding in Pandanus axils. A small number of $A e$. polynesiensis $(0.2 \%)$ were also found.

Table 3 Results of special survey on crab holes for breeding of $A e$. polynesiensis larvae

\begin{tabular}{|c|c|c|c|c|c|}
\hline \multirow[b]{2}{*}{ Village } & \multirow[b]{2}{*}{$\begin{array}{l}\text { No. of holes } \\
\text { examined }\end{array}$} & \multirow[b]{2}{*}{$\begin{array}{l}\text { No. of holes } \\
\text { with water }\end{array}$} & \multicolumn{3}{|c|}{ Holes with larvae } \\
\hline & & & Number & $\begin{array}{l}\text { Proportion to } \\
\text { total holes } \\
\text { examined }\end{array}$ & $\begin{array}{l}\text { Proportion to } \\
\text { holes with } \\
\text { water }\end{array}$ \\
\hline Mulinuu & 60 & 25 & 17 & $28.3 \%$ & $68.0 \%$ \\
\hline Moataa & 30 & 16 & 6 & 20.0 & 37.5 \\
\hline Vaiala & 30 & 4 & 0 & 0 & 0 \\
\hline Samea & 6 & 1 & 0 & 0 & 0 \\
\hline Faailoloo & 10 & 9 & 0 & 0 & 0 \\
\hline Lalovi & 10 & 2 & 0 & 0 & 0 \\
\hline
\end{tabular}


In each Pandanus plant, the leaf axils are located from approximately one foot to six feet above the ground. The breeding species in each axil were vertically not even. In this connection, a special survey was made in Pandanus plant in three villages of Upolu Island. As shown in Table 4, it was found that Ae. tutuilae prefers upper axils of a plant.

During the control trial of larvae by DDT spraying to leaf axils of Pandanus, it was found that the prevalence of Ae. tutuilae in the axils was much higher in the postcontrol surveys than in the pre-control surveys. It can be understood that $A e$. tutuilae larvae prefer newly-grown axils located in the upper part of a plant which are apparently not contaminated with insecticide applied before.

Seasonal prevalence of the breeding species in leaf axils of Pandanus was studied on a triweekly basis in 23 registered plants during the period July 1970 to June 1971, covering a whole year. As shown in Table 5, no remarkable seasonal prevalence was observed so far, except a slight increase in $A e$. Samoanus, at the expense of Ae.tutuilae and Ae. oceanicus. It should be pointed out that the plants under observation during the year round period were undergoing growth and developmental changes.

Freycinetia plant: Freycinetia is a creeping plant common in forested area of both Upolu and Savaii Islands of Western Samoa. Each leaf axil of the plant holds a small amount of water enough to harbour only one or two mosquito larvae. Since each plant, sometimes even 10 to 20 meters high, has a numerous axils, the total number of mosquito larvae which can breed in one plant of Freycinetia may be tremendous.

All the larvae collected from Freycinetia axils were Ae. samoanus.

Taro and giant taro: Taro plant, Colocasia sp., as well as giant taro, Alocasia sp., is planted in and around every village in Western Samoa. These are essential staple food for the people of the country. The axils of taro and giant taro hold water and very often harbour mosquito larvae. Usually

Table 4 Vertical distribution of mosquito larvae in leaf axils of Pandanus plants

\begin{tabular}{|c|c|c|c|c|c|c|}
\hline \multirow{2}{*}{$\begin{array}{l}\text { Location of axils } \\
\text { from the top }\end{array}$} & \multirow{2}{*}{$\begin{array}{l}\text { No. of axils } \\
\text { under survey }\end{array}$} & \multirow{2}{*}{$\begin{array}{l}\text { Total no. } \\
\text { of larvae } \\
\text { collected }\end{array}$} & \multicolumn{3}{|c|}{ Relative prevalence of each species $(\%)$} & \multirow{2}{*}{$\begin{array}{l}\text { Average no. } \\
\text { of larvae } \\
\text { per axil }\end{array}$} \\
\hline & & & $\begin{array}{c}\text { Aedes } \\
\text { samoanus }\end{array}$ & $\begin{array}{c}\text { Aedes } \\
\text { tutuilae }\end{array}$ & $\begin{array}{c}\text { Aedes } \\
\text { oceanicus }\end{array}$ & \\
\hline 1st- 3rd & 170 & 883 & 45.9 & 20.7 & 33.4 & 5.2 \\
\hline 4 th- 6 th & 142 & 503 & 51.3 & 5.0 & 43.7 & 4.2 \\
\hline 7 th -9 th & 50 & 176 & 34.1 & 2.8 & 63.1 & 3.5 \\
\hline 10 th-12th & 18 & 76 & 43.4 & 2.6 & 53.9 & 4.2 \\
\hline 13 th- 15 th & 18 & 25 & 56.0 & 0 & 44.0 & 1.4 \\
\hline 16 th-18th & 6 & 8 & 12.5 & 0 & 87.5 & 1.3 \\
\hline Overall & 404 & 1671 & 46.1 & 12.9 & 41.0 & 4.1 \\
\hline
\end{tabular}

Table 5 Results of a whole year survey of mosquito larvae in the 23 registered Pandanus plants

\begin{tabular}{lcccccc}
\multicolumn{1}{c}{ Date } & $\begin{array}{c}\text { No. of } \\
\text { surveys } \\
\text { made }\end{array}$ & $\begin{array}{c}\text { Total no. } \\
\text { of larvae } \\
\text { collected }\end{array}$ & $\begin{array}{c}\text { Redes } \\
\text { samoanus }\end{array}$ & $\begin{array}{c}\text { Aedes } \\
\text { tutuilae }\end{array}$ & $\begin{array}{c}\text { Aedes } \\
\text { oceanicus }\end{array}$ & $\begin{array}{c}\text { Aedes } \\
\text { polynesiensis }\end{array}$ \\
\hline Jul-Sep 1970 & 5 & 2775 & 79.1 & 9.2 & 11.7 & 0 \\
Oct-Dec 1970 & 4 & 1991 & 83.6 & 11.9 & 4.5 & 0 \\
Jan-Mar 1971 & 4 & 1491 & 88.3 & 7.9 & 3.8 & 0 \\
Apr-Jun 1971 & 5 & 2042 & 94.0 & 2.9 & 3.0 & 0.1 \\
Overall & 18 & 8299 & 85.5 & 8.1 & 6.4 & 0.02
\end{tabular}


more larvae are found in the axils of giant taro than those of taro, because of its capability to hold more water. Since no difference of breeding species between two kinds of the plants was observed, the results were combined.

Almost all the mosquito larvae (99.97\%) in the leaf axils of taro and giant taro were Ae. oceanicus. A small number of $A e$. polynesiensis and Ae. samoanus were also collected. It is open to question whether Ae. samoanus really breeds in the axils, since the larvae used to stick to the inside wall of collecting pipette and might be contaminated to the other collecting bottles.

Pineapple plant: It is rather difficult to find water in leaf axils of pineapple plant enough to harbour mosquito larvae, since they are planted in the sun and their axils are small.

Only Ae. oceanicus larvae were found in the axils.

\section{DISCUSSION}

\section{Breeding habits and distribution of Stego- myia mosquitoes}

In Western Samoa, the larvae of Aedes (Stegomyia) mosquitoes breed in artificial and natural containers or collections, but rarely in leaf axils of plants.

It can be concluded that in Western Samoa Ae. aegypti is the preferable breeder in artificial containers, especially drums, tyres and motor parts in the close proximity of houses. They were found all over the country, not only in the populated and civilized town area such as Apia, but also in the rural and inland areas of Savaii Island.

Ae. polynesiensis seems to be a plastic species, breeding in a wide range of both artificial and natural containers, but preferable breeder in natural containers. They are the only species breeding in crab holes, and are the predominant breeder in tree holes, coconut shells, rock holes, canoes and tin cans. They were collected also from leaf axils of Pandanus and taro plants, but the number was very small.

Since Ae. aegypti and Ae. polynesiensis breed together in such habitats like drums and tyres, the single-larva-per-container survey method tends to underestimate the population of either one.

Adult density of Ae.polynesiensis is rather high all over the country, except in the inland high altitude areas far from human activities, where neither artificial containers nor coconut trees are present. Its density is extremely high in the coastal areas with positive crab holes, sometimes reaching the density of 400 to 500 mosquitoes per man hour on human bait. In such areas, crab holes may play a major role producing the adult population of Ae. polyesiensis.

Unlike the other two Stegomyias, Ae. upolensis larvae were rarely collected, partly because the present collections were made mainly in the close proximity of human activities. This species is undoubtedly a forest mosquito. The role of Ae. upolensis in actual transmission of the filariasis is open to question, since man-mosquito contact might be much less than Ae. polynesiensis or Ae. samoanus.

2. Breeding habits and distribution of Finlaya mosquitoes

In Western Samoa, all the three Aedes (Finlaya) mosquitoes are exclusive breeders in leaf axils of plants, and each species has their favourite plant(s). Ae. samoanus larvae are the only species breeding in Freycinetia axils. They also breed in Pandanus axils, but abundantly only on Upolu Island. Ae. tutuilae larvae breed only in Pandanus axils, prefering young axils located in the upper part of the plant. This species is the minority of the three Finlaya mosquitoes. Ae. oceanicus larvae breed in taro, pineapple and Pandanus plants.

As mentioned above, Pandanus axils harbour, in general, three Finlaya mosquitoes, i.e. Ae. samoanus, Ae.tutuilae, and Ae. oceanicus. However, the breakdown of the three species in the axils is geographically inconsistent.

As shown in Table 6, Ae. samoanus was found predominantly in the Pandanus axils of Upolu Island, being $74.0 \%$ of the total larvae collected. In Savaii Island, only $4.4 \%$ was Ae. samoanus, and Ae. oceanicus was predominant $(77.2 \%)$. In addition, in the northern parts of Savaii, no Ae. samoanus larvae have ever been collected from the 
Table 6 Geographical distribution of four species of mosquito larvae in leaf axils of Pandanus

\begin{tabular}{|c|c|c|c|c|c|c|}
\hline \multirow[b]{2}{*}{ Island } & \multirow{2}{*}{$\begin{array}{c}\text { No. of } \\
\text { bundles of } \\
\text { Pandanus } \\
\text { plants under } \\
\text { survey }\end{array}$} & \multirow{2}{*}{$\begin{array}{l}\text { Total no. } \\
\text { of larvae } \\
\text { collected }\end{array}$} & \multicolumn{4}{|c|}{ Relative prevalence of each species $(\%)$} \\
\hline & & & $\begin{array}{c}\text { Aedes } \\
\text { polynesiensis }\end{array}$ & $\begin{array}{c}\text { Aedes } \\
\text { samoanus }\end{array}$ & $\begin{array}{l}\text { Aedes } \\
\text { tutuilae }\end{array}$ & $\begin{array}{l}\text { Aedes } \\
\text { oceanicus }\end{array}$ \\
\hline Upolu & 261 & 24981 & 0.16 & 74.0 & 7.8 & 18.0 \\
\hline Savaii & 28 & 1578 & 0.8 & 4.4 & 17.6 & 77.2 \\
\hline Apolima & 5 & 172 & 0 & 0 & 9.9 & 90.1 \\
\hline Manono & 5 & 168 & 0 & 0 & 6.5 & 93.5 \\
\hline Overall & 299 & 26899 & 0.2 & 69.0 & 8.4 & 22.4 \\
\hline
\end{tabular}

axils so far; and in the eastern and southern Savaii, Ae. samoanus larvae were present in the axils, but much less than Ae. oceanicus larvae. In two small islands of Apolima and Manono, which are located between Upolu and Savaii, no Ae. samoanus larvae were collected from the axils, Ae, oceanicus being predominant.

In Tutuila Island of American Samoa, which is located east of Upolu, it was reported by Ramalingam $(1965,1968$ ) that Ae. samoanus larvae were never collected from Pandanus axils, although they were abundant in Freycinetia axils.

Therefore, the distribution of Ae. samoanus larvae in Pandanus axils seems geographically not gradual but patchy; that is, from east to west, negative in Tutuila, positive and predominant in Upolu, negative both in Manono and Apolima, positive but scarce in the southern and eastern parts of Savaii, and negative in the northern parts of Savaii.

Taking into consideration that Ae. samoanus larvae breed in Freycinetia axils whereever the plant grows, it is presumed that the original breeding sites of Ae. samoamus might be Freycinetia axils and only the ecological or physiological colonies which have adapted to Pandanus can breed in their axils.

3. Role of Freycinetia and Pandanus axils in producing adult population of Ae. samoanus

As far as larvicidal application concerns, it is essentially needed to know what habitat plays a major role for producing adult population. In this connection, the following observations on the density of female Ae. samoanus may be informative.

(1) High density of Ae. samoanus was observed in inland villages which are located more than 100 meters away from the coast, than in coastal villages. Average density of Ae. samoanus per man hour was 61.0 in 47 stations of coastal villages; and 169.8 in 37 stations in inland villages.

(2) High density of Ae. samoanus was also observed in the stations close to forests, than those far from the forests. Average density per man hour was 159.5 in 54 stations less than 500 meters away from forests; and 17.9 in 30 stations more than 500 meters away from forests. (In this case, the "forests" mean the areas marked as "bush" on the $1: 20,000$ map of Western Samoa.)

(3) Although no or scarce breeding of Ae. samoanus was observed in Pandanus axils of Savaii Island, density of Ae. samoanus was higher in Savaii, which is covered, in general, by more dense forests than Upolu Island. Average density per man hour was 502.3 in 14 stations of Savaii, while 108.9 in 84 stations of Upolu.

(4) Even in the northern parts of Savaii, where no Ae. samoanus breeds in Pandanus axils, high density of Ae. samoanus was recorded.

Taking the above observations into consideration, it can be presumed with reasonable certainity, if not definitely, that, for producing adult population of Ae. samoanus, Freycinetia might play a major role, at least in the areas less than 500 meters away from forests. Unfortunately, most of the villages of Western Samoa are located in the abovementioned areas. It should be pointed out that Freycinetia axils are one of the most 
difficult habitats to be treated by larvicide, because the plant grows in forests and the axils are found as high as 20 meters above the ground.

\section{ACKNOWLEDGEMENT}

The authors wish to express their thanks to Dr. J. C. Thieme, the former Director of Health, Western Samoa; to Dr. L. Penaia and all staff of the Filariasis Control Project in Western Samoa, for their cooperation. Thanks are also due to Professor C. Y. Chow, the former Regional Adviser on Vector Biology and Control, the WHO Regional Office for the Western Pacific; Dr. J. H. Hirshman, the former WHO Representative for the South Pacific; and to Dr. Tin Maung Maung, WHO Epidemiologist, Epidemiological Surveillance Team, for their guidance.

\section{REFERENCES}

Belkin, J. N. (1962): The mosquitoes of the South Pacific. 2 Vols., Univ. of Calf. Press, Berkeley.

Bonnet, D. D. and H. Chapman (1956): The importance of mosquito breeding in tree holes with special reference to the problem in Tahiti. Mosq. News, 16 : 301-305.

Bonnet, D. D. and H. Chapman (1958): The larval habitats of Aedes polynesiensis Marks in Tahiti and methods of control. Am. J. Trop. Med. Hyg., 7 : 512-518.

Hitchcock, J. C. (1971) : Transmission of subperiodic filariasis in Tonga by Aedes oceanicus Belkin. Trans. R. Soc. Trop. Med. Hyg., 65 : 408-409.

Iyengar, M. O. T. (1965) : Epidemiology of filariasis in the South Pacific. South Pacific Commission Tech. Paper, No. 148.

Jackowski, L. A., Jr. (1954) : Filariasis in American Samoa. V. Bionomics of the principal vector Aedes polynesiensis Marks. Am. J. Hyg., $60: 186-203$.

Ramalingam, S. (1965): The mosquito fauna of
Samoa and Tonga and its relation to subperiodic bancroftian filariasis. $\mathrm{Ph}$. D. Thesis, Univ. of Calif., $172 \mathrm{pp}$.

Ramalingam, S. (1968): The epidemiology of filarial transmission in Samoa and Tonga. Am. J. Trop. Med. Parasitol., $62: 305-324$.

Ramalingam, S. and J. N. Belkin (1964): Vectors of subperiodic bancroftian filariasis in the Samoa-Tonga area. Nature (Lond.), 201 : 105106.

Ramalingam, S. and J. N. Belkin (1965): Two new Aedes from Tonga and Samoa. Contrib. Am. Entomol. Inst., 1 : 1-10.

Suzuki, T. and J. H. Hirshman (1977): Distribution and density of Aedes aegypti in the South Pacific. New Zealand Med. J., 85 : 374380 .

\section{摘 要}

西サモアに打けるフィラリア症および デング熱媒介蚊の発生源に関する知見

1969 年から 1971 年に至る間，南太平洋西无ア国に おいて, フィラリア症の媒介蚊 (Aedes (Stegomyia) polynesiensis, Ae. (S.) upolensis, Ae. (Finlaya) samoanus) およびデング熱の媒介蚊 (Ae. (S.) aegypti) の発生源について, 広範な調查を行なった. Ae.aegypti 注屋周辺の人工容器から発生し, 樹洞からの発生はき わめてわずかであった。 この種は，内陸部や僻地も含 め, 西サモア国の全域で発生が認められた. Ae.polynesiensis は, 人工㧍よび自然容器の雨方発生が認め られるが，後者をより好むよらである。 カニの穴にはも っぱらこの種だけが生息する．上述の両種は，同一の発 生源に共存することが多く，したがって，いわゆる“一 発生源一匹採集法”による調查では，どちらの種も分 布を過少評価するおるれがある.

Ae. upolensis は森林の蚊であり，その幼虫は樹洞か ら1度採集されたにすぎない。

Freycinetia の葉鞘からは, Ae. samoanus のみが発生 し，タロとパインアップルの葉鞘からは, Ae. oceanicus のみが発生する.この両種は，また，Pandanus の葉䩗 からも発生するが, Ae. tutuilae は, Pandanus の葉䩗 が唯一の発生源である. 